\title{
The Effect of Hypochlorite on the Germination of Spores of Clostridium bifermentans
}

\author{
By LINDA R. WYATT AND W. M. WAITES \\ Agricultural Research Council Food Research Institute, \\ Colney Lane, Norwich, NOR $70 F$
}

(Received 6 June 1973)

Spores of Clostridium bifermentans are more sensitive to chlorine, added as sodium hypochlorite, than spores of other clostridia or of Bacillus subtilis (Dye \& Mead, 1972). Spores of $C$. bifermentans or $B$. subtilis, damaged with chlorine, release dipicolinic acid (Dye \& Mead, I972; Alderton \& Halbrook, I97I) and may therefore have increased permeability. We have isolated mutants of $C$. bifermentans which germinate more slowly than the parent strain, possibly because of reduced permeability to germinants (Wyatt \& Waites, 197I). In view of these findings and the frequent use of chlorine as a disinfectant, we examined the effect of hypochlorite on the germination of mutant and parent spores.

\section{METHODS}

The parent strain of Clostridium bifermentans, the mutants derived from it and the preparation of spores were as described by Wyatt \& Waites (I97I). For treatment with hypochlorite, a suspension containing about $3.5 \mathrm{mg}$ dry wt spores was centrifuged at $15000 \mathrm{~g}$ for Io min and the spore pellet resuspended in $5 \mathrm{ml}$ of a solution of I00 $\mu \mathrm{g}$ sodium hypochlorite/ $\mathrm{ml}$ (B.D.H. Ltd, Poole) containing $50 \mu \mathrm{g}$ free chlorine. The suspension was incubated for Io min at $0{ }^{\circ} \mathrm{C}$ and centrifuged at $35000 \mathrm{~g}$ for $3 \mathrm{~min}$, and the spores were washed once in Io $\mathrm{ml}$ glass-distilled water and stored at $4{ }^{\circ} \mathrm{C}$ and then resuspended in $\mathrm{I} 5 \mathrm{ml}$ glass-distilled water and stored at $0^{\circ} \mathrm{C}$ until required for measurement of germination rates.

Free chlorine was measured by the Palin method (Palin, 1957) using DPD tablets (B.D.H. Ltd), the extinction being read at $553 \mathrm{~nm}$.

Germination rates were measured at $37^{\circ} \mathrm{C}$ either spectrophotometrically or microscopically as described by Waites \& Wyatt (I97I). Results are expressed as the maximum rate of decrease in $E_{600}$ calculated as a percentage of the initial extinction. The microscopic method was used when the germination rate was less than 0.4 and the rates calculated as described by Wyatt \& Waites (197I). Germination was in $\mathrm{NaCl}$ (I00 $\mathrm{mM}$ ) and organic germinants as described. Germinant concentrations were (mM): L-alanine (Ala), 50; L-arginine (Arg), 5; L-phenylalanine (Phe), 5; L-lactate, 25; and glycine (Gly), 50. In addition all the germinant mixtures contained sodium phosphate ( $83 \mathrm{~mm}$ ), $\mathrm{pH} 8 \cdot 0$ (with Ala), $\mathrm{pH} 6 \cdot 25$ (with Gly + Arg $+\mathrm{Phe}+\mathrm{L}$-lactate), or $\mathrm{pH} 7 \cdot 5$ (with all the other germinant mixtures).

\section{RESULTS}

Effect of hypochlorite on germination. The germination rate of spores of the wild-type was generally decreased slightly by pre-incubation at $0^{\circ} \mathrm{C}$ with hypochlorite containing Io $\mu \mathrm{g}$ free chlorine/ml, although the rate with L-alanine alone was almost doubled (Table I). 
Table I. Effect of hypochlorite on the germination of spores of wild-type and mutants of Clostridium bifermentans

The germination rates of spores treated with sodium hypochlorite were compared with those of untreated spores as described in Methods.

\begin{tabular}{|c|c|c|c|c|c|c|c|}
\hline \multirow[b]{2}{*}{ Mutant } & \multirow[b]{2}{*}{ Treatment } & \multicolumn{6}{|c|}{ Germination rate $(\% / \mathrm{min})$} \\
\hline & & With Ala & $\begin{array}{c}\text { With Ala } \\
\text { + Arg } \\
\text { + Phe }\end{array}$ & $\begin{array}{l}\text { With Ala } \\
\quad \text { + Phe } \\
\text { +L-lactate }\end{array}$ & $\begin{array}{l}\text { With Ala } \\
\text { +Arg } \\
\text { +L-lactate }\end{array}$ & $\begin{array}{c}\text { With Ala } \\
\text { + Arg } \\
\text { + Phe } \\
\text { + L-lac tate }\end{array}$ & $\begin{array}{l}\text { With Gly } \\
\text { + Arg } \\
\text { +Phe } \\
\text { + L-lactate }\end{array}$ \\
\hline Wild-type & $\begin{array}{l}\text { No hypochlorite } \\
\text { With hypochlorite }\end{array}$ & $\begin{array}{l}15 \\
29\end{array}$ & $\begin{array}{l}44 \\
39\end{array}$ & $\begin{array}{l}46 \\
35\end{array}$ & $\begin{array}{l}50 \\
4 I\end{array}$ & $\begin{array}{l}54 \\
40\end{array}$ & $\begin{array}{l}33 \\
28\end{array}$ \\
\hline $\mathbf{I}$ & $\begin{array}{l}\text { No hypochlorite } \\
\text { With hypochlorite }\end{array}$ & $\begin{array}{l}0.01 \\
2.0\end{array}$ & $\begin{array}{l}\mathrm{I} \cdot 8 \\
23\end{array}$ & $\begin{array}{l}6 \cdot 7 \\
0 \cdot 7\end{array}$ & $\begin{array}{l}2 \cdot 1 \\
0 \cdot 9\end{array}$ & $\begin{array}{l}\text { II } \\
33\end{array}$ & $\begin{array}{l}6 \cdot 9 \\
9 \cdot 6\end{array}$ \\
\hline 6 & $\begin{array}{l}\text { No hypochlorite } \\
\text { With hypochlorite }\end{array}$ & $\begin{array}{r}<0.001 \\
0.002\end{array}$ & $\begin{array}{c}<0.001 \\
0.9\end{array}$ & $\begin{array}{l}0.05 \\
4.6\end{array}$ & $\begin{array}{l}0.001 \\
1 \cdot 8\end{array}$ & $\begin{array}{l}0.4 \\
4.8\end{array}$ & $\begin{array}{l}<0.001 \\
<0.001\end{array}$ \\
\hline 3 & $\begin{array}{l}\text { No hypochlorite } \\
\text { With hypochlorite }\end{array}$ & $\begin{array}{l}<0.001 \\
<0.001\end{array}$ & $\begin{array}{c}<0.001 \\
0.7\end{array}$ & $\begin{array}{l}0.04 \\
8 \cdot 0\end{array}$ & $\begin{array}{l}0.001 \\
3.5\end{array}$ & $\begin{array}{l}0.5 \\
10\end{array}$ & $\begin{array}{r}<0.001 \\
0.001\end{array}$ \\
\hline
\end{tabular}

However, with four out of six of the germinant systems the rates of the mutants were increased by up to 3500 times and in some cases approached those of the wild-type. The greater increases generally occurred with germination systems containing Ala + Arg + Phe or $\mathrm{Ala}+\mathrm{Arg}+\mathrm{L}-\mathrm{lactate}$, and increases were small or absent when germination was with Gly + Arg + Phe + L-lactate. The presence of 100 or 250 mM-sodium phosphate $(\mathrm{pH} 7 \cdot 0)$ during incubation with hypochlorite did not alter the effect on germination rates although the $\mathrm{pH}$ at the beginning of the incubation was dependent on the concentration of buffer. During the incubation the $\mathrm{pH}$ changed from $8 \cdot 0$ to $7 \cdot 3$ (unbuffered), $6 \cdot 8$ to $6 \cdot 3$ (I00 $\mathrm{mM}$ ) or remained at $6.8(250 \mathrm{~mm})$. The concentration of free chlorine decreased during the incubation from Io $\mu \mathrm{g} / \mathrm{ml}$ to less than $5 \mu \mathrm{g} / \mathrm{ml}$.

\section{DISCUSSION}

Incubation with a solution of sodium hypochlorite increased the germination rate of spores of mutants of Clostridium bifermentans by up to 3500 -fold and in some cases to about that of the wild-type. An iodophor increased colony formation by spores of Bacillus subtilis (Cousins \& Allan, 1967) and the oxidizing agent, sodium perborate, increased the germination rate of spores of $B$. cereus (Cochran \& Ordal, 1973). We have found that hypochlorite treatment results in about a $60 \%$ decrease in viable spores and Dye \& Mead (1972) reported that similar concentrations of free chlorine rapidly killed spores of $C$. bifermentans. Previously we have produced more uniform and slightly greater increases in germination rate by treatment of spores of the mutants with $0 \cdot 1$ M-sodium hydroxide at $4{ }^{\circ} \mathrm{C}$. Such treatment removes protein (Wyatt \& Waites, 197I), possibly from the spore coat, and may increase the permeability of the spores to germinants (Waites, Wyatt \& Arthur, 1972). Hypochlorite may act in a similar way, and this would explain the release of dipicolinic acid after chlorine treatment (Alderton \& Halbrook, 197I; Dye \& Mead, 1972).

The efficiency of chlorinating agents as disinfectants may be due, in part, to stimulation of spore germination followed by inactivation of the germinated spore.

The germination rates of the wild-type were slightly decreased by the hypochlorite in contrast to the effect on the mutants. We have found that the wild-type is more sensitive 
than the mutants to lysozyme after incubation with sodium hydroxide (unpublished). This difference and the greater inhibition of the germination of the wild-type by hypochlorite may be due to differences between the spore coats of the wild-type and the mutants. The spore coat may act as a barrier to hypochlorite. Of the species examined by Dye \& Mead (1972), spores of Bacillus subtilis were the most resistant to hypochlorite and loss of viability was preceded by a pronounced lag. If the spore coat is associated with hypochlorite resistance then such a result might be expected with spores with thick coats like those of $B$. subtilis (Wood, 1972), while spores of Clostridium bifermentans, which have much thinner coats (Waites et al. 1972), might be expected to be more sensitive to hypochlorite. Spores of B. subtilis deficient in cortex but with apparently normal spore coats are resistant to octanol (Fukuda \& Gilvarg, I968) and spore coats thus play a role in the resistance of spores to surfactants. Removal of spore-coat material might then be expected to make spores more sensitive to hypochlorite. Sodium hydroxide removes protein from spore coats of B. subtilis (Wood, 1972), and Cousins \& Allan (1967) have shown that hypochlorite and sodium hydroxide act synergistically to kill spores of $B$. subtilis.

We are grateful to Dr G. C. Mead and Dr J. L. Peel for useful discussions.

\section{REFERENCES}

Alderton, G. \& HalbrooK, W. U. (I97I). Action of chlorine on bacterial spores. Bacteriological Proceedings, $\mathbf{1 2}$.

Cochran, S. A. \& Ordal, Z. J. (1973). Oxidative activation of Bacillus cereus spores. Applied Microbiology 25, I73-I79.

Cousins, C. M. \& Allan, C. D. (1967). Sporicidal properties of some halogens. Journal of Applied Bacteriology 30, $\mathrm{I} 68-\mathrm{I} 74$.

DYE, M. \& MEAD, G. C. (1972). The effect of chlorine on the viability of clostridial spores. Journal of Food Technology 7, 173-18I.

FuKuDA, A. \& Gilvarg, C. (1968). The relationship of dipicolinate and lysine biosynthesis in Bacillus megaterium. Journal of Biological Chemistry 243, 387 I-3876.

PaLIN, A. T. (1957). The determination of free and combined chlorine in water by the use of diethyl-pphenylene diamine. Journal of the American Water Works Association 49, 873-880.

WAITES, W. M. \& WYATT, L. R. (1971). Germination of spores of Clostridium bifermentans by certain amino acids, lactate and pyruvate in the presence of sodium or potassium ions. Journal of General Microbiology 67, $215-222$.

Waites, W. M., WyATt, L. R. \& ARTHUR, B. (1972). Effect of alkali treatment on the germination and morphology of spores of Clostridium bifermentans. In Spores, vol. 5, pp. 430-436. Edited by H. O. Halvorson, R. Hanson and L. L. Campbell. Washington, D.C.: American Society for Microbiology.

Wood, D. A. (1972). Sporulation in Bacillus subtilis. Properties and time of synthesis of alkali-soluble protein of the spore coat. Biochemical Journal 130, 505-5I4.

WyatT, L. R. \& WaITES, W. M. (197I). Studies with spores of Clostridium bifermentans; comparison of germination mutants. In Spore Research 297 , pp. I23-132. Edited by A. N. Barker, G. W. Gould and J. Wolf. London: Academic Press. 